\title{
屋根上積雪の経時的な雪質変化および摩擦特性
}

\section{Change of Snow Condition and Frictional Property of Snow with Duration on Roof}

\author{
伊 東 敏 幸*1 ・高 倉 政 寛*2 \\ Toshiyuki Ito Masahiro Takakura \\ 苫米地 司*3 \\ Tsukasa Tomabechi
}

\section{SYNOPSIS}

For systematic sliding of roof snow, appropriate evaluation of the frictional properties between roof snow and roofing materials is needed. Snow generally slides off a roof several days after accumulating on the roof due to changes in snow condition (new snow $\rightarrow$ compacted snow $\rightarrow$ granular snow) caused by the transfer of heat from attic space. In this study, we experimentally investigated the temporal changes of roof snow and the accompanying changes in frictional properties between the snow and roofing material. The results showed that the size of snow particles gradually increases after snow has accumulated on the roof, and frictional resistance between the snow and coated steel sheets greatly decreases. Within $24 \sim 48$ hours after accumulation of snow on the roof, the frictional resistance of the snow decreases to about one-third of that of new snow. Thereafter, there is almost no change in frictional resistance. The results of this study show that consideration of the temporal decrease in frictional resistance between roof snow and roofing materials is important for planning systematic sliding of roof snow.

Keywords : roof snow, snow sliding, frictional resistance, snow condition

\section{1.はじめに}

多雪地域における建築物の屋根上皘雪を自然滑落 処理することは，皘雪荷重の低減や雪下ろし作業中 の転落事故防止に有効である。しかし，屋根雪を規 則的かつ安全に滑落させなければ，落雪による人身 事故や過剩皘雪による建物崩壊などにつながること
から，屋根雪の滑落現象を規則的に制御する必要が ある。屋根雪の滑落は屋根营材と屋根雪下層部亡の 摩擦性状に支配される。すなわち，屋根菆材の表面 性状と摩擦面付近の雪質並びにその含水状態に対応 した滑雪性状を明らかにし，その特性を考虑した滑 落雪計画を行う必要がある。

* 1 北海道工業大学・講師 (工博)

* 2 北海道工業大学大学院

*3 北海道工業大学・教授 (工博)

[本稿受理 : 1998年 5 月25日, 修正原稿受理 : 1998年 8 月31日, 討論期限 : 1999年12月31日] 
一般住宅のように屋内暖房があり天井断熱を施し た小屋裹を持つ緩勾配屋根における屋根雪の滑落状 況を観察すると, 降雪の直後に滑落するのは稀であ り, 多くの場合, 数時間むしくは数日経過した後に 滑落し，その場合における屋根雪の最下層部はザラ

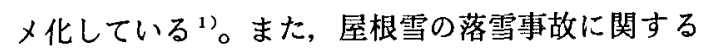
研究によると, 落雪事故の多くは多量の降雪があっ た日の数日後に発生している ${ }^{2)}$ 。これらの現象をみ る之, 屋根雪の滑落抵抗力は降雪後の経時過程にお いて減少していると考えられる。このことに関して, 異なる雪質の摩摖抵抗力を評価した報告では，雪粒 の粗大化に伴って摩摖抵抗力が減少することを指摘 している ${ }^{3)}$ 。このことから, 降雪後の経時過程にお いて屋根面付近の雪は変態し, その粒径が粗大化す ることによって摩擦抵抗力が減少して数日経過した ときに滑落現象が発生していると考える。

このように, 小屋裹からの伝熱がある屋根におい ては, 降雪後の経時過程において屋根面付近の雪質 が変化して摩擦抵抗力が減少すると考えられること から，屋根雪の規則的な滑落を制御するためには， 経時的な雪質変化およびその摩擦特性を明らかにす る必要がある。しかし，このことに関する研究報告 は, 極めて少ない現状にある。屋根雪の滑落性状に 関する既往の研究をみると，材料の表面性状が及ぼ す滑雪特性を評価したものが多く，その評価に用い ている屋根雪モテルは水体，しまり雪あるいはザラ メ雪であるが，経時的に変化する雪質を想定した屋 根雪モデルを用いた例はないい つ。

以上のことから，本研究は勾配屋根における滑落 雪処理を規則的に制御するための資料となる程時的 な雪質変化およびその变化過程における摩摖特性を 明らかにすることを目的とする。はじめに，札幌お よび新庄における降雪後, 数日間の外気温推移につ いて整理した。その結果を基に小屋裹からの伝熱を 想定したモデル実験を行い，摩擦界面付近の雪質変 化の状態を明らかにし，さらにその状態における摩 擦抵抗力を測定した。また，経時的な雪質变化を利 用することによって屋根雪の滑落促進を行うことが 出来ることを示した。

\section{2. 降雪後の気温特性および屋根雪状態}

\section{1 小屋轰からの伝熱がある屋根面の温度}

地上に堆積した雪は，その雪質が時間の経過に伴っ て変化し, 新雪からざらめ雪へと変態してゅく。こ のような雪の変態過程を定量的に示す指標の一つに 雪粒の粒径がある。これまでの雪粒の粗大化に関す

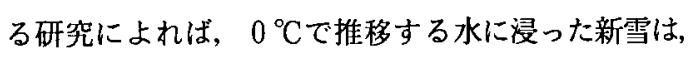
その平均粒径が 130 時間後に $0.3 \mathrm{~mm}$ から $1.1 \mathrm{~mm}$ ま で粗大化することを観察し，雪粒径 $(\mathrm{mm})$ の增加 が経過時間 (hour) の $1 / 3$ 乗に比例することが明ら かにされている ${ }^{8)}$ 。このように，雪粒の周曲に水分 が介在している場合では, 数日間のうちに新雪がざ らめ雪へと変態する。

ここで, 札幌市の一般的な小屋裹構造の戸建住宅 について，厳冬期である2月の屋根茸材表面温度を 測定した結果では，次のことが明らかとなっている。 屋根上に雪が $10 \sim 15 \mathrm{~cm}$ 堆積した状態における屋根 葺材の表面温度は, 外気温が $-6{ }^{\circ} \mathrm{C}$ 程度 (小屋裏温 度 : $2 \sim 4{ }^{\circ} \mathrm{C}$, 居室温度 : $18^{\circ} \mathrm{C}$ 程度) まで低下した 場合であっても $0{ }^{\circ} \mathrm{C}$ 若干上回る温度で推移する。 この場合, 屋根咠材と屋根雪との界面では融雪水が 若干ながらも発生する状態になる ${ }^{3)}$ 。従って, 暖房 を行っている建物の屋根雪は, 屋根裹からの伝熱の 影響を受けて雪質が変態していると考えられる。

\section{2 札幌および新庄における降雪後の気温特性}

先に述へたように, 屋根面付近の雪は, 積雪後の 時間経過に伴ってその雪粒径が変化する。雪粒径の 変化は, 融雪水の発生に影響されることから, 屋根 面温度を支配する降雪後の外気温推移を把握する必 要がある。このことから，降雪があった日から数日 後までの外気温推移について分析した。この分析は 年間降雪量が多かった1980年11月〜1981年 4 月にお ける札幌之新庄を対象に，気象官署の観湘資料を用 いた。

1 日の降雪深が $5 \mathrm{~cm}$ 以上あった日を基点とした 数日後までの日平均気温の推移について整理すると 表ー 1 よなる。なお，この表は以下の 2 条件を基に テータを抽出している。 
表一 1 札幌之新庄における降雪後の外気温推移

\begin{tabular}{|c|c|c|c|c|c|c|c|}
\hline 気潒官署:札幌 & 当日 & 2日目 & 3日目 & 4日目 & 5日目 & 6日目 & 7日目 \\
\hline YEAR/MONTH/DAY & 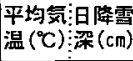 & \begin{tabular}{|l} 
平均気: 降零 \\
温 $\left.{ }^{\circ} \mathrm{C}\right)$ 深 $(\mathrm{cm})$
\end{tabular} & \begin{tabular}{|l} 
平均気: 日降需 $\left({ }^{\circ} \mathrm{C}\right)$ \\
深 \\
(cm)
\end{tabular} & \begin{tabular}{|l} 
平均気 淐降霓 \\
$\left({ }^{\circ} \mathrm{C}\right)$
\end{tabular} & \begin{tabular}{|l|}
$\mid$ 平均気 : 目降雪 \\
温 $\left({ }^{\circ} \mathrm{C}\right)$
\end{tabular} & $\mid$\begin{tabular}{|l} 
平均気泪降霓 \\
$\left({ }^{\circ} \mathrm{C}\right)$
\end{tabular} & $\begin{array}{l}\text { 平均箱泪降需 }\left({ }^{\circ} \mathrm{C}\right) \text { 深 }(\mathrm{cm})\end{array}$ \\
\hline $80 / 12 / 14$ & -2.5 & -0.4 & $-1.7 \vdots$ & -1.0 & $-1.6:$ & $=48$ & \\
\hline $80 / 12 / 19$ & $-4.8: 77$ & -2.3 & -2.11 & -4.1 & 5.1181 & -3.6 & \\
\hline $81 / 01 / 02$ & $-2.2 \vdots 11$ & $-0.3 !$ & -2.4 & 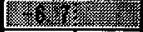 & 6.0 & $2.57=11$ & $5.0 \% 23$ \\
\hline $81 / 01 / 06$ & 6.008 & $5.7 \%$ & -5.0 & $-2.4 \vdots$ & $-2.1 \vdots 19$ & $5.7: 15$ & 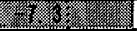 \\
\hline $81 / 01 / 10$ & $-2.1 ! 19$ & $-5.77 \% 15$ & 78 r & 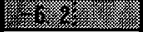 & -5.2 & $60 \% 2$ & $-5,5 \%$ \\
\hline $81 / 01 / 21$ & $-\gamma 2 \%$ & (1) & $4.4 .4 \% 17$ & $-2.3 \vdots$ & - & 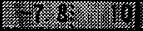 & (3) \\
\hline $81 / 01 / 25$ & -6 - & - & 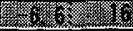 & $-5.6 \% 79$ & $-5.5 \%$ & $-4.6: 10$ & $-2.5:$ \\
\hline $81 / 01 / 28$ & $-6.6 \%$ & $5.5 \% 8$ & $\begin{array}{ll}-4,6 & 10\end{array}$ & -2.5 & $-2.0 \vdots$ & 3,3 & $-2.5 \vdots$ \\
\hline $81 / 01 / 31$ & -2.5 & $-2.0 \vdots$ & $-3.3:$ & -2.5 & $-0.9:$ & $-2.2 !$ & -1.35 \\
\hline $81 / 02 / 04$ & $-0.9 \vdots$ & -2.2 & $-1.3 \vdots$ & $-1.6 !$ & 3. 24 & -4.3 & -1.8 \\
\hline $81 / 02 / 19$ & -1.35 & $-3.0 \vdots$ & $3.5: 2$ & 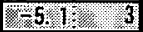 & $-5.3 \%$ & 4 & maty \\
\hline $81 / 03 / 07$ & $-2.4 \vdots$ & 4.22 & $-6.07=9$ & 60.08 & $-3.5: 16$ & & \\
\hline
\end{tabular}

\begin{tabular}{|c|c|c|c|c|c|c|c|}
\hline 気象官署: 新庄 & 当日 & 2日目 & 3日目 & 4日目 & 5日目 & 6日目 & 7日目 \\
\hline YEAR/MONTH/DAY & $\begin{array}{l}\text { 平均気: 泪隄雪 } \\
\left({ }^{\circ} \mathrm{C}\right)\end{array}$ & $\begin{array}{l}\text { 平均䒽汨降雪 } \\
\text { 温 }\left({ }^{\circ} \mathrm{C}\right) \text { 深 }(\mathrm{cm})\end{array}$ & 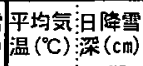 & \begin{tabular}{|l}
$\mid$ 平均気汨降需 \\
( $\mathrm{C}$ C) 深 (cm)
\end{tabular} & $\begin{array}{l}\text { 平均気汨降電 } \\
\text { 温 }\left({ }^{\circ C}\right) \text { 深 }(\mathrm{cm})\end{array}$ & \begin{tabular}{|l} 
平均気泪降霄) \\
温 $\left({ }^{\circ} \mathrm{C}\right)$ 深 $(\mathrm{cm})$
\end{tabular} & 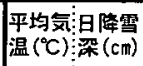 \\
\hline $80 / 12 / 19$ & $-1.7: \quad 10$ & $-3.0 \vdots$ & $-2.0 \vdots$ & $-0.1 \vdots 10$ & & & \\
\hline $80 / 12 / 27$ & $-0.5:$ & $-0.7 \vdots 30$ & $0.2 \vdots$ & $-0.2 \vdots$ & & & \\
\hline $81 / 01 / 03$ & $1.6 \vdots$ & $-0.1 \vdots 17$ & $-0.8:$ & $-2.9 \vdots \quad 45$ & $-3.48: 13$ & -1.2 & \\
\hline $81 / 01 / 10$ & -0.9 & $-2.6 \vdots 22$ & 3.7 & $4.8 \quad 26$ & $19.14 \% 12$ & -55 & 1248 \\
\hline $81 / 01 / 13$ & $48 \quad 26$ & X) & $\mid-5: 5: 34$ & $-4.8 \quad 2$ & -3.7 ? 18 & -1.0 & -1.7 \\
\hline $81 / 01 / 16$ & $\begin{array}{c}-4.8 \\
\end{array}$ & -3.7 .18 & $-1.0: \quad 12$ & $-1.7 \vdots 20$ & $3.12=20$ & -4. 6 & $40 \%$ \\
\hline $81 / 01 / 19$ & $\begin{array}{lll}-1.7 ! & 20 \\
\end{array}$ & -3.1120 & -46724 & 4.0 & -1.5 & & \\
\hline $81 / 01 / 25$ & -2.3 & -4.21 .4 & $\frac{-4.2}{4} \quad 17$ & 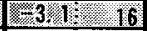 & $-2.3 !$ & -1.9 & \\
\hline $81 / 02 / 08$ & $-1.1 !$ & $-1.6: 7$ & $0.2 !$ & $-2.3 \vdots 13$ & 0.5 & $\vdots$ & \\
\hline $81 / 02 / 19$ & $-0.7 \vdots$ & $-1.6 \vdots$ & -2.9 & (-3. 3) & $-4.8: 35$ & -0.7 & -1.9 \\
\hline $81 / 02 / 22$ & - 3. $33 \quad 17$ & -4.8 . 5 & $-0.7 \quad 3$ & $-1.9:$ & 4.6 . 5 & 5.0 & 4.5 \\
\hline $81 / 02 / 25$ & $-1.9 \vdots \quad 6$ & 46.65 & $50 \% 25$ & -45 & $\begin{array}{ll}3.8 & 10 \\
\end{array}$ & & \\
\hline $81 / 03 / 08$ & -0.9 & $-1.5 i$ & $-1.0 \vdots \quad 9$ & $-2.4 !$ & & & \\
\hline
\end{tabular}

(1) $5 \mathrm{~cm}$ 以上の降雪があった日の後, 日最高気温 が $2{ }^{\circ} \mathrm{C}$ 未満で推移する 7 日後までの期間を記載 した。

(2)数日間連続して降雪があった場合については, 札幌の $1 / 25$ で示したように，降雪当日を含め て 3 日間の連続降雪までを一事象とし，4 日目 以降の降雪は次の事象として記載した。 表のように，(1)，(2)の条件を満たした降雪日は札幌 で12事象，新庄では13事象であった。これらの事象 について日平均気温の推移を温度別に分類してみる と表中の網掛けの上うになる。札幌の場合をみると， 降雪当日の日平均気温は，1/21および $1 / 25$ では $-6{ }^{\circ} \mathrm{C}$ 未満となるものの，他の日については，通常 に暖房を行っている建物の場合，ある程度の皘雪が あれば屋根葺材と屋根雪との界面に融雪水が発生し 得る外気温となっている。さらに2 日目以降につい てみてみると，殆どの日において融雪水が発生し得 る温度範囲にあり，1/25の場合は 4 日目以降にこ
の状態となる。一方，新庄の場合をみると，降雪当 日は何れの日においてむ平均気温が- $6{ }^{\circ} \mathrm{C}$ 以上となっ ており，2 日目以降で一時的に気温が下がる日も若 干存在するが，全体的には継続的に融雪水が発生す る外気温推移となっている。

これらの結果をみると，札幌および新庄における 暧房している建物の屋根雪は，小屋裏からの伝熱に よる融雪水の発生によって, 経時的に雪粒径が粗大 化するむのと考えられる。このように，屋根雪の滑 落抵抗力を評価する場合, 時間経過に伴う摩擦界面 付近の雪物性変化を考虑する必要があると言える。

\section{3.雪質およひ摩擦抵抗力の経時的変化}

前述した降雪後の温度推移のように，小屋裏から の伝熱がある屋根では，屋根面付近の雪が経時的に 粗大化することから，粗大化の状態およびその摩擦 特性を実験的に検討する。小屋裹からの伝熱状態の 違いによる粗大化の進行速度，および材料の違いに 
よる特性を評価するため，小屋裏温度を変化させた モデル実験を数種類の屋根莫材を対象として行った。

\section{1 実験の方法}

実際の屋根における小屋裏からの伝熱を想定する ため，図ー 1 に示すような試験体を用いたモテル実 験を行った。図に示すように，試験体はランバーコ ア合板上に $20 \mathrm{~mm}$ 厚のフォームポリスチレン板お よびパネルヒーターを載せ，その上にある $9 \mathrm{~mm}$ 厚 の野地板に屋根葷材を貼り付けている。このような 試験体をー8〜-5 ${ }^{\circ} \mathrm{C} て ゙$ 降雪した日にパネルヒーター の電源を絶った状㦔で屋外に水平状態で放置し，屋 根荤材上に自然状態で $10 \mathrm{~cm}$ 以上積雪させた。その 後, 雪が載っだ状癿の試験体を一 $5{ }^{\circ} \mathrm{C}$ の低温室内へ 移動し, 積雪深 $10 \mathrm{~cm}$ 以上の雪を取り除いた後，パ ネルヒーターに通電した。パネルヒーター表面の温 度は，予備実験によって屋根葷材表面の温度が $0^{\circ} \mathrm{C}$ を若干上回るような温度になる表一 2 に示す 4 通り とした。なお, 低温室の温度 $\left(-5{ }^{\circ} \mathrm{C}\right)$ は札幌にお ける $1 ・ 2$ 月の平均外気温である $-4.5^{\circ} \mathrm{C}$ を想定し ている。実験時の積雪密度は何れも $180 \sim 210 \mathrm{~kg} / \mathrm{m}^{3}$ であった。

低温室内に移動した試験体を用い，次のように動 摩擦係数の測定および摩擦界面付近の雪の锖察を行っ た。動摩擦抵抗力の測定は, 低温室内で水平型滑雪 試験装置を用いて実施した ${ }^{9)}$ 。测定は所定時間を経 過した時点で，各試験体上の雪を $10 \mathrm{~cm}$ 角の大きさ に成形した雪ブロックを $4 \mathrm{~mm} / \mathrm{sec}$ の速度で水平滑 動させ，そのときの摩擦抵抗力をロードセルを用い て测定した。併せて，摩擦界面付近の雪質を評価す るため, 摩擦測定の直後に雪ブロック下面の雪を一
部切除し，黒い樹脂板上に薄く載せてビテオカメラ （倍率10倍）を用いて観察した。なお，この実験は 継続的に行ったので，測定・観察時以外の時は雪ブ ロックを紙製の枠で仕切り，その周囲をしまり雪で 覆うことによって周囲からの冷却を防いだ。この測 定・観察は，表一 2 に示す経過時間毎に行い，各試 料は 2 枚ずつとし，1枚の試料につき摩擦抵抗力を 3 回測定した。なお，既往の研究をみると静摩擦抵 抗力と動摩擦抵抗力は線形関係にあることから，本 実験では動摩擦抵抗力に限って测定した ${ }^{10)}$ 。

このモテル実験に供した試料は，表一 3 に示すよ うな皘雪地域で多用されている屋根草材とした。塗 装鋼鈑 2 種類は滑落雪の特性に影響を及ぼす表面粗 さが異なる材料とし，光沢塗装鋼鈑よりも若千表面 粗さが大きく撥水性のある材料として叙装ステンレ ス鋼鈑，表面が平滑で親水性に優れるフロート板ガ ラスを用いて本実験における材料特性を評洒した。 なお，板ガラスの実験ではパネルヒーター上に直に 試料を載せている。

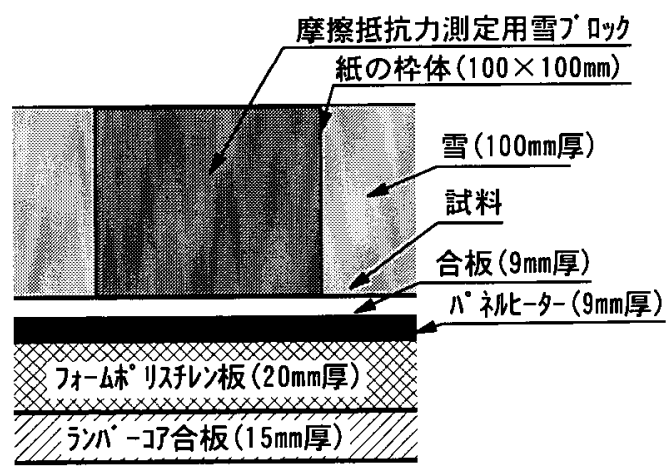

図ー1 モテル実験に用いた試験体の概要

表ー 2 雪粒の観察および摩擦抵抗力の測定間隔

\begin{tabular}{|c|c|c|c|c|c|c|c|}
\hline \multirow{2}{*}{ 実験NNo. } & \multirow{2}{*}{$n^{\circ}$ 䃿ヒ-タ-の温度 } & \multicolumn{6}{|c|}{ 動摩擦抵抗力の測定（O印） } \\
\hline & & 6時間後 & 12 時間後 & 24時間後 & 48時間後 & 72 時間後 & 96 時間後 \\
\hline No. 1 & 1. $2^{\circ} \mathrm{C}$ & 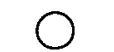 & 0 & 0 & 0 & 0 & O \\
\hline No. 2 & 1. $5^{\circ} \mathrm{C}$ & 0 & 0 & 0 & 0 & 0 & 0 \\
\hline No. 3 & 1. $9^{\circ} \mathrm{C}$ & 0 & 0 & 0 & 0 & 0 & 0 \\
\hline No. 4 & $2.4^{\circ} \mathrm{C}$ & 0 & 0 & 0 & 0 & 0 & $* 1$ \\
\hline
\end{tabular}

*1 雪ブロックの融雪が著しい状態であった。 


\section{2 経時的な雪質変化の観察結果}

小屋裏からの伝熱を想定したモデル実験による経 時的な雪質变化を観察した。その結果を写真ー 1 に 示す。なおこれらの写真はパネルヒーター温度が $2.4^{\circ} \mathrm{C}$ の場合（屋根苦材の表面温度は $0 \sim 0.3^{\circ} \mathrm{C}$ ）に
おける光沢塗装鋼鈑の観察結果を示している。経時 的な雪粒の形状変化をみると，写真のように， 6 時 間を経過した時点までは新雪時と同様な細かい雪粒 であり雪の焼結変態は殆ど確認できない。しかし, 実験開始から12時間を経過すると雪粒は $0.3 \mathrm{~mm}$ 程

表 -3 試料の概要

\begin{tabular}{|c|c|c|c|}
\hline 試料名称 & 概要 & $R z$ & $\theta$ \\
\hline 加一板力゙ ラス & $\begin{array}{l}\text { フ口-ト板ガ ラ久（JISＲ 3202） } \\
\text { 無色，材厚 } 5 \mathrm{~mm}\end{array}$ & $0.15 \mu \mathrm{m}$ & $25.4^{\circ}$ \\
\hline 光沢塗装鋼板 & $\begin{array}{l}\text { 塗装溶融亜鈶めっき鋼板 (JIS G 3312) } \\
\text { 青色, 材厚 } 0.35 \mathrm{~mm}\end{array}$ & 2. $43 \mu \mathrm{m}$ & $60.2^{\circ}$ \\
\hline 艶消塗装鋼板 & $\begin{array}{l}\text { 塗装溶融亜鈶-5\%?ル汸么合金めつき鋼板 } \\
(\text { JIS G 3318) 艶消青色, 材厚0. } 35 \mathrm{~mm}\end{array}$ & $23.00 \mu \mathrm{m}$ & $71.6^{\circ}$ \\
\hline 塗装ステンルス鋼板 & $\begin{array}{l}\text { 塗装不ンルス鋼板（JIS G 3320） } \\
\text { 澧消茶色，材厚 } 0.35 \mathrm{~mm}\end{array}$ & 3. $80 \mu \mathrm{m}$ & $77.8^{\circ}$ \\
\hline
\end{tabular}

注) Rzは試料表面の10点平均粗さであり, $\theta$ は試料と蒸留水との接触角である。

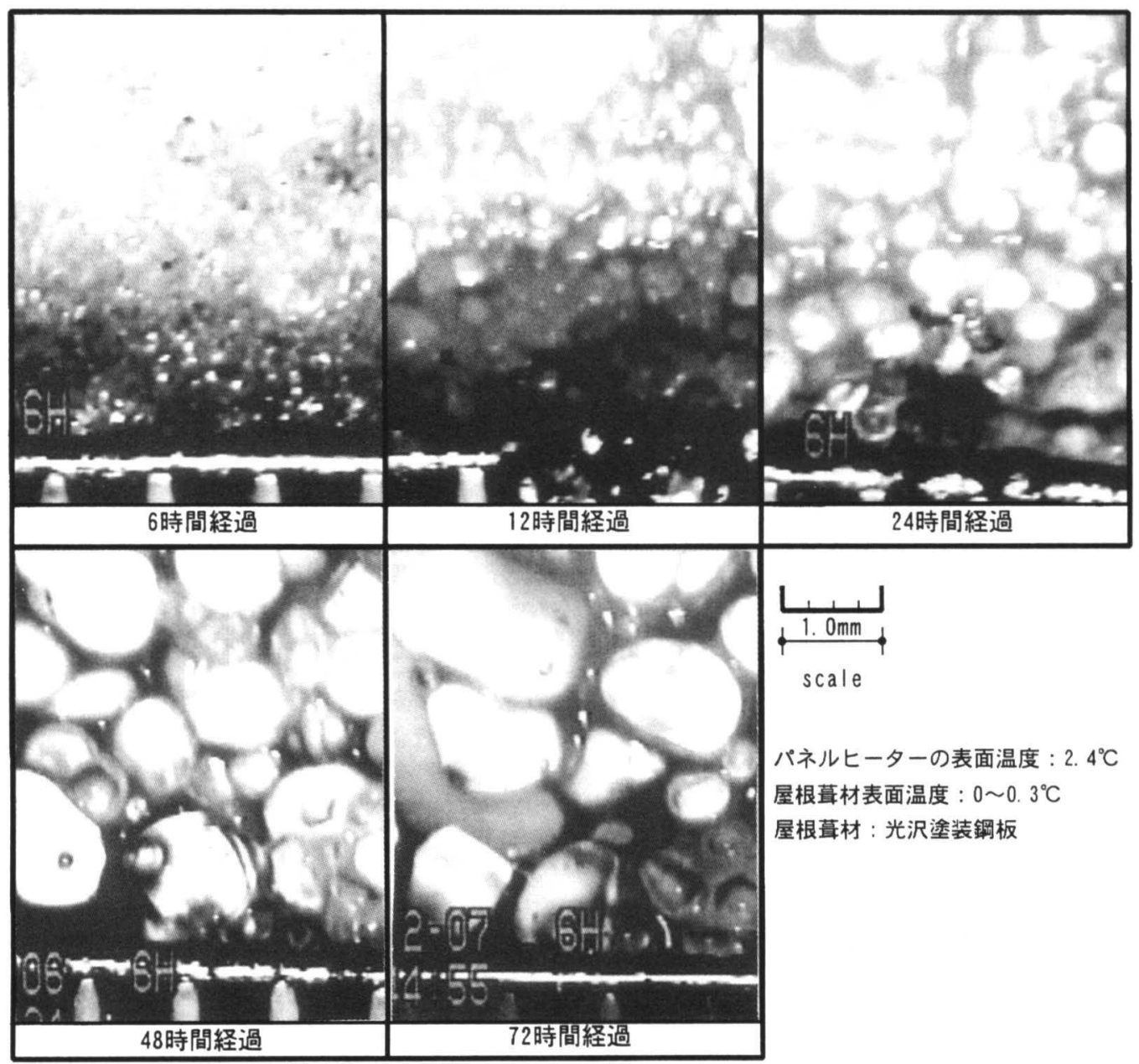

写真 -1 経時的な雪質の変化 
度，24時間経過した時点では $0.5 \mathrm{~mm}$ 程度の球状粒 子に変化していることが分かる。さらに時間の経過 に伴って雪粒の粗大化が進行し, 実験開始加ら48時 間経過した時点では $0.5 \sim 1.0 \mathrm{~mm}, 72$ 時間経過した 時点では $1.0 \sim 2.0 \mathrm{~mm}$ の粒径にまで成長している ことが確認できる。なお，パネルヒーター温度がこ れよりも低い $1.2^{\circ} \mathrm{C}$ 場合, 雪粒径が $1 \mathrm{~mm}$ 程度に なるまでの経過時間は64時間要している。

このように, ある程度の皘雪があり, 屋根裏から の伝熱があると, 経時的に屋根面付近の雪は顕著に 変態し, その雪粒が粗大化する。その場合, 屋根の

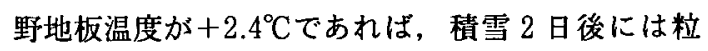
径 $1 \mathrm{~mm}$ 程度のザラメ雪が屋根面付近に存在するこ とになる。この雪粒の粗大化は外気温, 小屋重温度 および屋根雪の積雪深に影響を受けるものであるこ とから，屋根面の温熱環境を雪の粗大化に有効な状 態にすることで，雪粒の粗大化を促進することは可 能と考えられる。

\section{3 雪質が変化する屋根雪の摩擦特性}

小屋裹からの伝熱によって経時的に雪粒が粗大化 することから，積雪後における経時的な摩擦係数の 変化について評価する。モテル実験における経時的 な動摩擦係数の変化を 3 通りのパネルヒーター温度 についてみると図ー2 となる。図のように，各屋根 葷材と雪ブロックの動摩擦係数は, 何れの温度にお いても経時的に減少する傾向を示し，48時間経過ま でに測定開始時の $1 / 3$ 程度となる。その後48時間 を経過すると動摩擦係数は，ほぼ一定の值となる。 この傾向に対するパネル温度の影響をみると, 何れ の屋根亘材も温度が高いほど動摩擦係数の減少率が 若干大きくなる傾向にある。材料の違いによる影響 をみると, 図の $1.2^{\circ} \mathrm{C}$ に示すように, 板ガラスは経 時的な摩摖係数の減少率が極めて大きく，48時間経 過での動摩擦係数は0.1程度まで減少する。この減 少率が大きくなる要因は, 細かい雪粒が湿閏となる 6〜12時間経過時点では, 雪とガラスの間に作用す る粘着抵抗が大きく作用し，その後雪粒が粗大化す ると, 雪粒とガラス表面との接触状態が変化して粘 着抵抗力が減少するためである。光沢塗装鋼鈑と塗
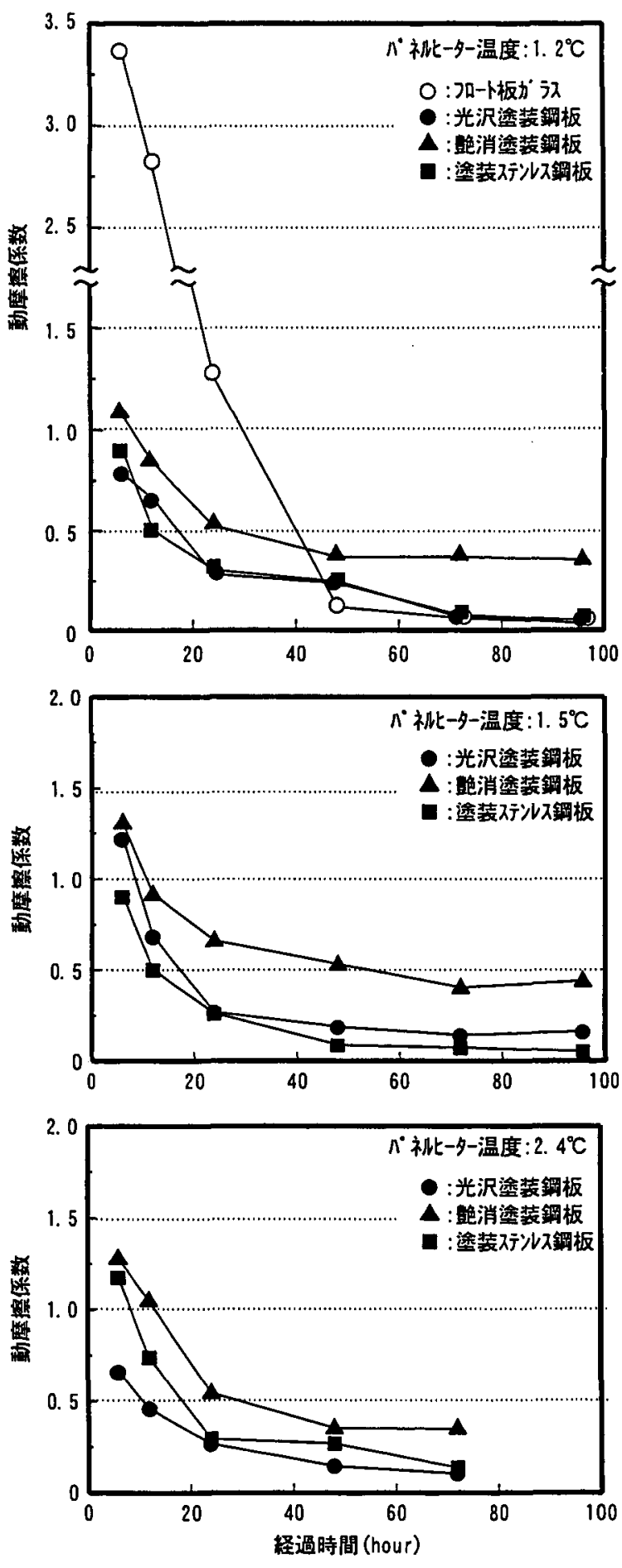

図一2 経時的な動摩擦抵抗力の変化 
装ステンレス鋼鈑における動摩擦係数の滅少傾向は 同様であり，パネル温度は $1.5^{\circ} \mathrm{C}$ 以上であれば 48 時 間以上経過すると動摩擦係数は約 0.2 以下まで減少 する。一方，唈消塗装鋼鈑は表面が粗いため，パネ ル温度が $2.4^{\circ} \mathrm{C}$ 場合でも 48 時間以上経過したとき の動摩擦係数は0.4程度となる。

このように, 積雪後における屋根面付近の雪と屋 根营材との動摩擦係数は，48時間経過頃まで経時的 に顕著な減少を示すことが分かった。このことは， 雪粒径と摩擦係数との関係を示した既往研究からみ てむ妥当な結果であり ${ }^{3)}$, 経時的な雪粒の粗大化に 依存する現象と考えられる。

\section{4. 雪質変化を利用した滑落雪制御に関する考察}

前述のように，屋根裹から何らかの伀熱によって 屋根面がプラス温度になるような屋根の場合，屋根 面付近の雪が融雪しながら，その雪粒が粗大化し， 粗大化に伴って屋根雪の摩擦抵抗力か減少する。従っ て, 外気温が水点下で推移する場合においても，屋 根面に適切な熱供給を行うことによって，強制融雪 のような過大な熱量を使用することなく，経時的に 雪質が変化する現象を利用した滑落雪の促進が可能 になることを示唆している。すなわち，降雪直後か ら強制的な融雪を行って滑落雪を促進する場合は, 屋根面付近の雪を融解させ, 摩擦界面に融雪水を多 量に介在させることによって屋根雪の滑落を促進す ることになる ${ }^{11}$ 。しかし，経時的な雪粒の粗大化を 利用する場合は，雪粒の粗大化に必要な融雪水を発 生させるための熱量を供給すれば良く，摩擦界面に 多量の水を介在させる必要がないことから，屋根面 に供給する熱量は少なくて良い。なお，雪粒の粗大 化を利用して滑落雪を制御する場合は，雪粒の粗大 化に有効な伝熱量および粗大化の速度を適切に評価 し，摩擦抵抗力が減少するために必要な所要時間を 推定する必要がある。さらに，豪雪時のように連続 的に多量の降雪がある場合は，粗大化に要する時間 を短縮させるための方策, あるいは許容量以上の積 雪になる場合の雪処理方法を考えなければならない。 これらの点については，雪質変化を利用した滑落雪 制御に対する今後の研究課題である。

\section{5.まとめ}

小屋裹からの伝熱がある屋根における積雪の経時 的な雪質変化，およびその摩擦特性を実験的に検討 した。その結果, 積雪後48時間経過すると, 屋根面 付近の雪粒倩は $1 \mathrm{~mm}$ 程度まで粗大化し, 粗大化し た雪と屋根草材との動摩擦係数は新雪時の $1 / 3$ 程度 まで減少することが分かった。このことから積雪後 における経時的な雪質変化を利用することによって 屋根雪の滑落雪を促進させることが可能になると考 える。経時的な雪質变化を利用した滑落雪制御を行 うには，雪粒の粗大化に有効な伝熱量および粗大化 の速度を適切に評洒し，粗大化に伴う摩擦抵抗力の 変化特性を材料別に明らかにする必要がある。

\section{参考文献}

1）竹中隆一, 他 3 名: 皘雪寒冷地域における膜ドーム の膜上積雪処理に関する研究（その 2$)$ ，自然落雪 と温風融雪の効果に関する解析, 第 9 回寒地技術 ンポジゥム講演論文集, pp.7-12, 1993.12

2）山形敏明：北海道における市街地を対象とした雪氷 防災に関する基礎的研究，北海道工業大学学位論文， 1997.3

3）高倉政莧，伊東敏幸，苫米地司：経時的に雪質変化 した屋根上皘雪と劲装鋼鈑との摩擦特性，日本建築 学会構造系論文集, 第510号, pp.45-50, 1998.8

4) 前田博司 : 金属板屋根における積雪の滑落, 日本雪 水学会誌，第41卷 3 号, pp.199-204, 1978.12

5 ) 渡辺正朋, 平井和喜 : 屋根草材と屋根雪の摩擦に関 する研究 (その 2 ), 屋根茸材に対する雪水の骬走 速度および動摩擦, 日本雪工学会誌, 第 9 号, pp.4-15, 1988.12

6）苫米地司，他 3 名 : 膜構造物の屋根雪処理に関する 基礎的研究，日本建築学会構造系論文報告集，第 426 号, pp.99-105, 1991.8

7）㞎東敏幸 : 積雪地域における公配屋根の材料設計お よび維持保全に関する研究, 東北大学学位論文, 1995.12

8) 対馬勝年 : 水に浸った雪の粗大化, 日本雪水学会誌 第40巻 4 号, pp.1-11, 1978.12

9）伊東敏幸, 苫米地司, 星野政幸 : 劣化した塗装鋼鈑 の表面性状之滑雪性について, 日本雪工学会誌, Vol.10, No.2, pp.2-10, 1994.4

10）渡辺正朋, 滝田貢 : 屋根雪の滑雪制御に関する基䃈 的考察, 日本雪工学会誌, Vol.13 No.1, pp.3-12, 1997.1

11）苫米地司，高倉政筧，伊東敏幸：屋根荤材の表面粗 さが滑雪現象に及ぼす影䒜, 日本雪工学会誌, Vol.12 No.3, pp.3-9, 1996.7 